\title{
The Effect of Job Resources on Employee Engagament with Workplace Spirituality and Professional Identity as Mediation for Millennial Generation Employees of PT. Bank Muamalat Wes Jakarta Region
}

\author{
Driyati Nur Anika and Mafizatun Nurhayati
}

\section{ABSTRACT}

\begin{abstract}
A well functioning organization is the output of healthy human resources, committed and always motivated which can also be called employee engagement. This study aims to prove the existence of direct and indirect impact between job resources and employee engagement. Quantitative research that uses premier data through questionnaries with a sample of 96 respondents with saturated sampling technique and analysis method using SEM-PIs. The results of this study indicate that job resources have no effect on employee engagement, job resources have a positive effect on workplace spirituality, workplace spirituality has no effect on employee engagement, job resources have positive effect on professional identity, professional identity have a positive effect on employee engagement, workplace spirituality is unable to mediate between job resources and employee engagement, and professional identity plays a mediating role between job resources and employee engagement.
\end{abstract}

Keywords: Job Resources, Workplace Spirituality, Professional Identity, Employee Engagement, Millenial Generation.

\author{
Submitted : July 29, 2021 \\ Published : September 01, 2021 \\ ISSN: $2507-1076$ \\ DOI: $10.24018 /$ ejbmr.2021.6.5.1044 \\ Driyati Nur Anika \\ Master of Management, Mercu Buana \\ University, Jakarta, Indonesia. \\ (e-mail: Driyatinur@gmail.com) \\ Mafizatun Nurhayati \\ Master of Management, Mercu Buana \\ University, Jakarta, Indonesia. \\ (e-mail: \\ mafizatun.nurhayati@mercubuana.ac.id)
}

*Corresponding Author

\section{INTRODUCTION}

Human resources must better equip themselves with hard skill, soft skill, and brain skill [21]. PT. Bank Muamalat continuously during the vulnerable 2017-2019 using external consultants in conducting employee relationship surveys and producing scores at a moderate level for 3 years [9]. There is a significant difference The boby boomers generation, generation $x$, and generation $y$, especially generation $\mathrm{Y}$ which show the lowest level of involvement [9]. The level of involvement of the millennial workforce in Indonesia is only $25 \%$ partially involved, $9 \%$ of employees refuse to be involved and $66 \%$ of the millennial workforce partially involved [9] this can be interpreted that the millennial workforce is more concentrated on task work (as long as it is completed) - not the quality of the result, is reluctant to accept input and is only salary oriented.

According to [19] states that job resources can affect future involvement, which will predict organizational commitment. Job resources include the physical, psychological, social, and organizational aspects of the job [5] job resources are also aspects of the work environment that help in achieving work goals, stimulate personal growth, learning and development or reduces job demands [7]. A study of higher education staff members showed that professional identity was also considered an influential factor in employee engagement [32]. [25] suggests the relationship between professional identity and employee engagement but is carried out in the context of medical and educational industries.

Several studies have investigated several concepts regarding employee engagement including [10] and [17] which show that work resources have a positive effect on employee engagement, [12] and [22] which stated that spirituality in the workplace has an influence on employee engagement, [25] and [27] gives the result that professional identity has a positive effect on employee engagement. But not with results produced by [4] and [19] that job resources have no effect on employee engagement.

With the research gap found in previous research, this research was a conducted with the aim of reviewing the direct relationship and direct relationship between job resources and employee engagement in the practice of banking employees.

\section{LITERATURE REVIEW AND HYPOTHESIS DEVELOPMENT}

\section{A. Employee Engagement}

The Attachment of an employee is psychological influenced who can connect and commit to completing his work and is driven by a. an organization that has openness, supportive attitude, fairness, and trust as well as good communication between coworkers, b. communication technique, providing feedback and performance appraisal 
techniques owned by management and leadership, c. a work environment that has fairness [24]. In measuring employee engagement, vigor is used mental toughness at work, involvement in work and resilience in the face of adversity, dedication, enthusiasm, inspires and has pride and challenges and absorption, which is fully concentrated and happy to work [33].

\section{B. Job Resources}

Job resources predict personal resources such as selfefficacy, optimism, and self-esteem as well as work involvement [28], job resources can also be extrinsically motivating when they can fullfil the basic desires of employees [28] employability can also affect future engagement, which in turn will predict organizational commitment [33]. In measuring job resources, autonomy is used where employees can decide how - including when and where they do their work, skill variation the job demands a variety of different activities so that they can use a number of different skill and abilities that will lead to different types of work. Eliminate boredom on routine work, feedback where employee providers get information and get encouragement [35] and praise while working as well as opportunities for growth which include getting promotions and getting training accordance with their fields [5].

\section{Workplace Spirituality}

Workplace spirituality is related to strong employee affiliation, employee commitment and employee engagement due to a sense of wholeness and full involvement form oneself when carrying out work roles [22], according to [36], workplace spirituality is a person's perception about a workplace where it can help them find purpose in life, develop work related relationships and have alignment between the organization and employees. Measuring tools are used according to [39] including meaningful work where employees will have an attitude of feeling comfortable at work, feeling excited at work and feeling treated well by the company, a sense of community which proves that there is openness among employees have strong inner feeling among employees and a high sense of trust among employees, and positive organizational purpose which refers to employees to feel the positive values that exist in the company, are treated fairly in the organization and have the same goals as the organization.

\section{Professional Identity}

The development of professional identity is a dynamic process that link work roles with clear self-perceptions including interests, skills, professional goals, and values, and give meaning and orientation to one's profession [29]. And it is also a self-development process between feelings, emotions, beliefs and behaviors related to work and careers that exist within oneself [37], Professional identity also describes a person by identifying someone with social groups and categories that are owned based on their work [38]. When a person has a professional identity within them, they are more likely to give more energy and enthusiasm to work even though there is job dissatisfaction caused by the work environment. [38] in [26] use 5 (five) measuring tools in measuring professional identity namely Affirmation is the importance of a job and a sense of pleasure in work, In-dept exploration where employees will think about the advantages and disadvantages of being an employee and re-matching existing professions, Practies where employees will seek information about work and participate in conferences/seminars about the current profession, Identification with commitment employees have confidence and a sense of self understanding when working and Reconsideration of Commitment which states that employees will prepare himself for another career and will change his mind to become an employee in another company.

\section{E. Hypothesis Development}

There are differences in research results found in previous studies and based on previous theoretical studies, the researchers formulate hypotheses on the conceptual model in Fig. 1.

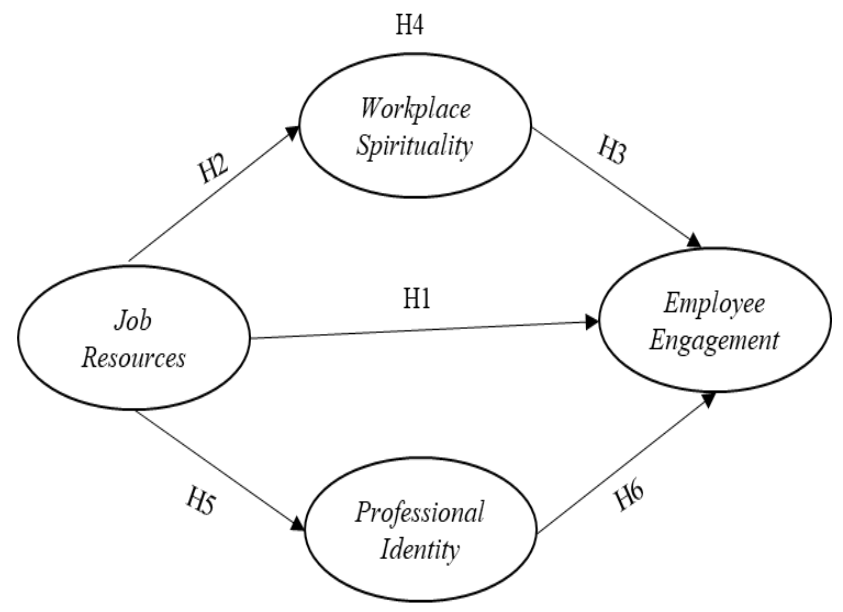

$\mathrm{H} 7$

Fig. 1. The Conceptual Model.

Job resources can increase employee engagement where job resources have factors including autonomy, skill variation and growth opportunities [5]. Job resources can also be extrinsically motivating when they can fulfill the basic desires of employees [10] besides that employees will be more attached to work if they are given autonomy and given better training [28], according to [33] stated that job resources affect future engagement, this is in line with the results of research conducted by [2] and [17] that job resources have a positive effect on employee engagement, so in this study to first hypothesis:

H1: Job resources has a positive effect on employee engagement.

The main meaning of job resources is that demand and resources initiate two relatively independent processes and explain well-being in the workplace [33] so that spirituality in the workplace is no longer just a worker's inner need, but about the need for a sense of belonging to be part of the workforce. community [34] as well as [7] which states that job resources are aspects of the working environment to help in achieving work objectives, provide personal growth, learning and development or reduce the demands of the job. The results of research conducted by [7] state that job resources have a positive influence on workplace spirituality, so the second hypothesis is: 
H2: Job resources has a positive effect on workplace spirituality.

Workplace spirituality is a recognition that employees have a purpose and meaning in their work, where work spirituality is not about religion, although people sometimes express their religious beliefs at work [43] Regardless of the usual work or attracting spirituality in the workplace related to strong employee affiliation, employee commitment and employee engagement [22]. The theory above is in line with the results of research conducted by [3] and [18] which state that workplace spirituality has a positive effect on employee engagement, so the third hypothesis is:

H3: Workplace spirituality has a positive effect on employee engagement.

Employee engagement is influenced by two factors: the situation and the individual, the situational factors in question are job resources, which are social and organization aspects in achieving goals and encouraging personal growth and development and individual factors, namely personal resources (work spirituality) [5] where companies recognizes that employees have an inner life that is nurtured and nurtures by work [34]. The results of research conducted by [18] state that workplace spirituality has a positive effect on employee engagement and research conducted by [7] shows that job resources have a positive effect on employee engagement so that based on the result of the two studies above it can be said that workplace spirituality can mediate job resources on employee engagement, so the fourth hypothesis is:

H4: Job resources has an indirect positive effect on employee engagement through the mediating effect of workplace spirituality.

Job resources can predict personal resources such as optimism in doing work and self-efficacy or individual belief of each employee in his ability to succeed in doing work [28]. While professional identity is a process of professional values that exist within an employee, identity with one's work and psychological unification within oneself. Research conducted by [15] states that job resources have a positive effect on professional identity, so the fifth hypothesis is:

H5: Job resources has a positive effect on professional identity.

As a self-concept, professional identity refers to an individual's understanding of the social impact of the profession and the importance of individual work which is the psychological basis for a person in doing his job well so as to achieve organizational goals. [42] revealed that professional identity has a positive influence on employee engagement. The theoretical study above is strengthened by the results of research conducted by [26] and research conducted by [29] which has results which is the same where professional identity has a positive influence on employee engagement, so the hypothesis that will be used is as follows:

H6: professional identity has a positive effect on employee engagement.

Factors that can affect employee engagement are at several levels starting with a broad organizational climate, certain job factors, professional and personal resources [15] Broad organization and certain job factors including aspects that exist in da lam job resources [5] while describing someone as a professional identity of workers who perform certain jobs and personal identification with the group based its work [38]. The results of research conducted by [14] stated that there was a positive relationship between professional identity and work engagement and the results of research conducted by [15] stated that job resources had a positive effect on professional identity, so based on the results of the two studies above, it can be said that professional identity can mediate job resources on employee engagement. then for the seventh hypothesis is:

H7: Job resources have an indirect positive effect employee engagement through the mediating effect of professional identity.

\section{RESEARCH METHODOLOGY}

The research design used is associative/ relationship which aims to determine the relationship or influence of two or more variables and the extent to which the relationship of the independent variable affects the dependent variable and to know the mediating variable directly/ indirectly [25]. The independent variable used in this study is job resources which are physical, psychological and social aspects that will be measured through the dimensions of autonomy, skill variation, performance feedback and opportunities to develop [5]. The dependent variable studied is employee engagement, which is a psychological state of employees to think positively about work and organization which is carried out by measuring through the dimensions of vigor, dedication and absorption [33]. The mediating variable studied is workplace spirituality, namely a person's perception of where they work that can help find life goals and have harmony between employees and the company [36] which will be measured through the dimensions of meaningful work, sense of community and positive organizational purpose [3] and other mediation is professional identity, which is the incorporation of one's job role as a worker with emotional feelings, interests and skills to do his job which will be measured through affirmation mediation, in dept exploration, practices, identification with commitment, and reconsideration of commitment.

Data collection was carried out using a saturated sample method where all members of the population of 96 employees will be used as samples. [25] The population used in this study is all employees of the main branch office for the West Jakarta area with the characteristics that these employees are permanent employees and millennial employees through questionnaire which will be provided through a google form and will be measured by a scale Likert 1-5 [25].

Data analysis will be carried out with the Structural Equation Model - Partial Least Square (SEM - PLS) by evaluating the measurement model and the structural model [25]. 


\section{RESEARCH RESULT}

\section{A. Descriptive Statistic of Demographic Characteristic}

Tables I and II are the results of responses from 96 respondents, where Table II will present the tendency of answers to the questionnaire according to the answer category by looking at the mean value of each statement based on the Five Box Methode [31], which is very low (1-1.80), low (1.81-2.60), moderate (2.61-3.40), high (3.41-4.20), very high (4.21-5.00).

TABLE I: THE Distribution OF ANY WeRs BASED ON THE DEMOGRAPHICS CHARACTERISTICS

\begin{tabular}{cccc}
\hline \multicolumn{4}{c}{ DEMOGRAPHICS CHARACTERISTICS } \\
\hline \multirow{2}{*}{ Category } & Description & $\begin{array}{c}\text { Frekuensi } \\
(\text { People })\end{array}$ & $\begin{array}{c}\text { Percentage } \\
(\%)\end{array}$ \\
\hline \multirow{2}{*}{ Gender } & Male & 45 & $47 \%$ \\
& Female & 51 & $53 \%$ \\
& Total & $\mathbf{9 6}$ & $\mathbf{1 0 0 \%}$ \\
\hline \multirow{2}{*}{ Age } & $<25$ Years & 25 & $26 \%$ \\
& 25 - 35 Years & 71 & $74 \%$ \\
Position & Total & $\mathbf{9 6}$ & $\mathbf{1 0 0 \%}$ \\
& Staff & 54 & $56 \%$ \\
& Head of Division & 13 & $14 \%$ \\
& Asisten / Manager & 29 & $30 \%$ \\
Educational & Total & $\mathbf{9 6}$ & $\mathbf{1 0 0 \%}$ \\
\hline Experience & SMA & 3 & $3 \%$ \\
& D3 & 15 & $16 \%$ \\
& S1 & 70 & $73 \%$ \\
& S2 & 8 & $8 \%$ \\
& Total & $\mathbf{9 6}$ & $\mathbf{1 0 0 \%}$ \\
\hline \multirow{3}{*}{ Branch Office } & Bintaro & 28 & $29 \%$ \\
& Fatmawati & 23 & $24 \%$ \\
& BSD & 25 & $26 \%$ \\
& Roxy & 20 & $21 \%$ \\
& Total & $\mathbf{9 6}$ & $\mathbf{1 0 0 \%}$ \\
\hline
\end{tabular}

Source: Data processed by researchers in 2021.

The distribution of respondents based on gender is dominated by women by $53 \%$, age is dominated by $25-35$ years by $74 \%$, position is dominated by staff by $56 \%$, last education is bachelor degree by $73 \%$ and fatmawati main branch office by $29 \%$.

Table II shows the tendency of answers to the questionnaire according to each statement through the mean indicator value in the high category namely (3.41-4.20), in the job resources variable it can be seen that the highest mean value of 3.85 is an indicator of getting a promotion (JR8), workplace spirituality, the highest mean value of 4.03 is an indicator of trust among employees (WS6) and feels a positive value in the company (WS7), professional identity, the highest mean value of 4.05 is an indicator of participating in conferences/seminars about the profession of work employee engagement the highest mean value is 3.89 , which is an indicator of mental toughness when working.

\section{B. Outer Model Measurement}

Table II shows the outer model testing which will test the validity and reliability of the validity testing model, which will be evaluated through convergent validity by looking at the loading factor value with the condition that the acceptable value is $>0.60$ and the AVE value is > 0.50 [30]. Loading factor that have a value of $<0.6$ will be excluded from the research model, namely on job resources with indicators of having the ability to innovate (JR1), the opportunity to determine the workplace (JR2), get encouragement and praise (JR7) and receive training in accordance with their field
(JR9), workplace spirituality on indicators of feeling comfortable at work (WS1) and enthusiastic at work (WS2), professional identity with indicators of the importance of a job (PI1) and feeling happy about work (PI2) and employee engagement on indicators of being happy with the next job (EE8) in Table II, the AVE section has met the AVE value > 0.50 , so it can be concluded that all constructs have met the convergent validity requirements.

And for reliability testing, it will be evaluated through the value of composite reliability and Cronbach's alpha $>0.70$ [30] so that by looking at Table II it can be concluded that the value of all constructs seen from the value of composite reliability and Cronbach's alpha can be declared reliable because it has a value of $>0.7$.

\section{Inner Model Measurement}

\begin{tabular}{cccc}
\multicolumn{4}{c}{ TABLE III: $\mathrm{R}^{2}$ VALUE, $\mathrm{Q}^{2}$, AND GOF } \\
\hline Variable & $\mathrm{R}^{2}$ & $\mathrm{Q}^{2}$ & $\mathrm{GoF}$ \\
\hline Job Resources & - & 0.890 & 0.511 \\
Employee Engagement & 0.675 & & \\
Professional Identity & 0.380 & & \\
Workplace Spirituality & 0.458 & & \\
\hline Source: Results of data analysis using SmartPLS Version 3.2.9 (2021) &
\end{tabular}

The value of $\mathrm{R}^{2}$ will explain the model's ability to explain the dependent variable. Employee engagement variables are influenced jointly by job resources, workplace spirituality, and professional identity variables by $67,5 \%$ while the remaining $32.5 \%$ is influenced by other factors not observed in this study, professional identity variable is influenced by job resources variable by $38 \%$ while the remaining $62 \%$ is influenced by other factors and the workplace spirituality variable is influenced by the job resources variable by $45.8 \%$ while the remaining $54.2 \%$ is influenced by other factors not observed in this study.

For testing predictive relevance, it has a value of 0.890 which proves that the model has strong predictive relevance because it is $>0.35$ [30], while the Gof value in this study has a value of 0.511 which means that the combined performance between models has a large GoF because > 0,36 [30].

The results of the above study indicate that:

H1: Rejected, a direct relationship between job resources toward employee engagement has a value of t-statistic of $1.579<t$-value 1,96 and $p$-value $>0.05$ then it can be said that job resources no significant effect on employee engagement. H2: Received a direct relationship between job resources on workplace spirituality has a value of $t$-statistic of $9.559>t$-value 1,96 and the value of $p$-value $0.000<0,05$, it can be said that job resources positive effect on workplace spirituality. H3: Rejected the direct relationship between workplace spirituality and employee engagement has a $t$ statistic value of $1.619<t$-value 1.96 and $p$-value $0.106>$ 0.05 so that workplace spirituality has no effect on employee engagement, H4: Rejected an indirect relationship mediated by workplace spirituality has a $t$-statistic value of $1.529<$ 1.96 with a $p$-value $0.127>0.05$ which mean that job resources have no effect on employee engagement mediated by workplace spirituality. H5: Received that the direct relationship between job resources and professional identity has a $t$-statistic value of $7.039>t$-value 1.96 and $p$-value $0.000<0.05$, it can be said that job resources have a positive effect on professional identity. H6: Received that the direct relationship between professional identity and employee 
engagement has a t-statistic value of $3.088>t$-value 1.96 and p-value $0.002<0.05$ so it can be said that professional identity has a positive effect on employee engagement. H7: Received that the indirect relationship mediated by professional identity has a $t$-statistic value of $2.767>1.96$ and p-value $0.006<0.005$, which means that job resources have a positive and significant effect on employee engagement mediated by professional identity.

TABLE II. RESUlt OF MEAN ANALYSIS, FACTOR LOADING >0.60, AVE >0.5, COMPOSITE RELIABILITY>0.7, CRONBACH’S ALPHA >0.7

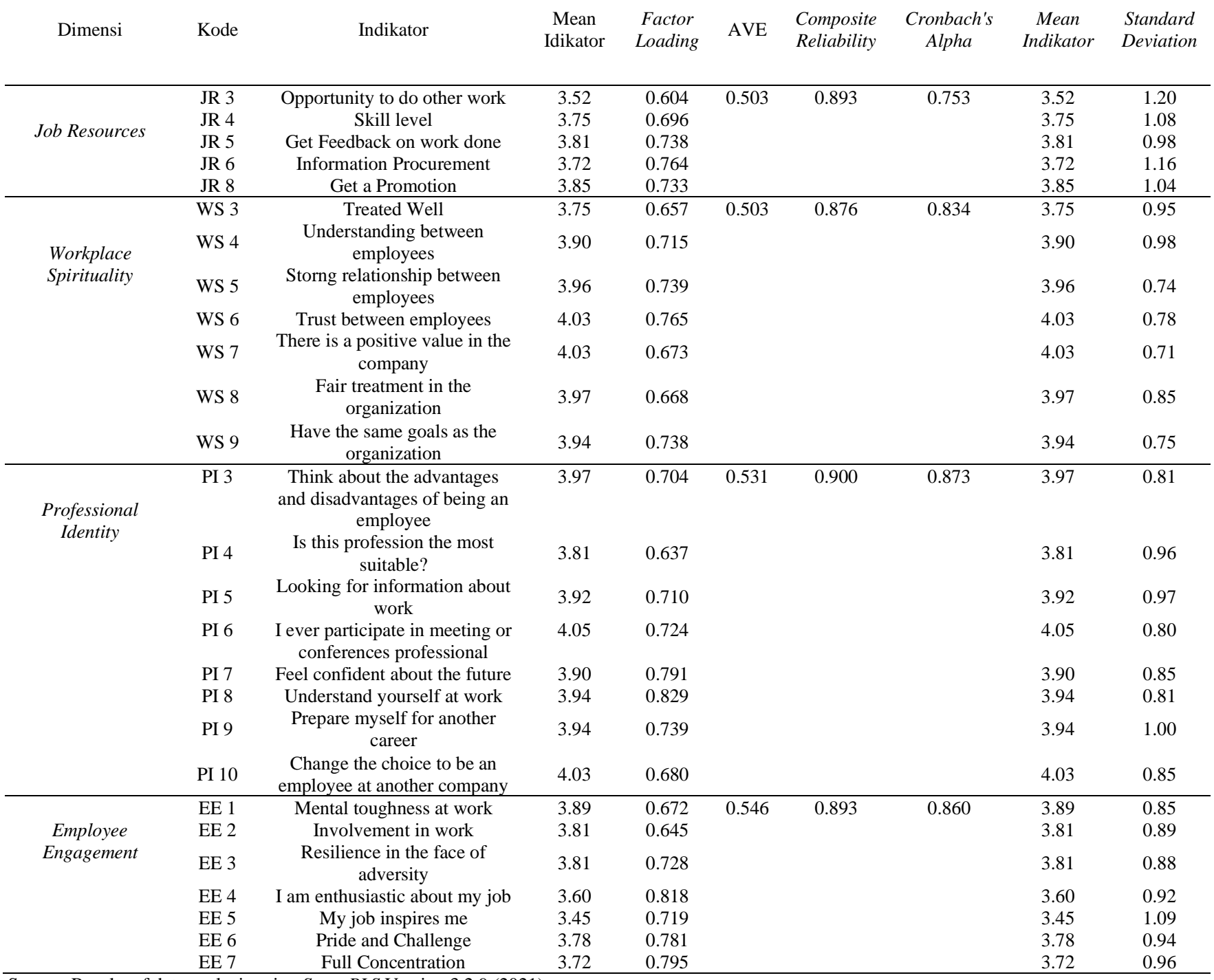

Source: Results of data analysis using SmartPLS Version 3.2.9 (2021).

TABLE IV: The VALUE OF PATH COEFFiCIENT, T-STATISTICS, AND P-VALUES

\begin{tabular}{|c|c|c|c|c|}
\hline Model Pathways & $\begin{array}{c}\text { Original } \\
\text { Sample }(\mathrm{O})\end{array}$ & T Statistics & $P$ Values & Influence \\
\hline \multicolumn{5}{|l|}{ Direct Effects } \\
\hline Job Resources -> Employee Engagement & 0.145 & 1.579 & 0.115 & \multirow{5}{*}{$\begin{array}{l}\text { Not signifikant } \\
\text { signifikant } \\
\text { signifikant } \\
\text { signifikant } \\
\text { Not signifikan }\end{array}$} \\
\hline Job Resources -> Workplace Spirituality & 0.677 & 9.559 & 0.000 & \\
\hline Job Resources -> Professional Identity & 0.617 & 7.039 & 0.000 & \\
\hline Professional Identity -> Employee Engagement & 0.476 & 3.088 & 0.002 & \\
\hline Workplace Spirituality -> Employee Engagement & 0.280 & 1.619 & 0.106 & \\
\hline \multicolumn{5}{|l|}{ Indirect Effects } \\
\hline Job Resources -> Professional Identity -> Employee Engagement & 0.293 & 2.767 & 0.006 & signifikant \\
\hline Job Resources -> Workplace Spirituality -> Employee Engagement & 0.189 & 1.529 & 0.127 & Not signifikant \\
\hline
\end{tabular}

Source: Results of data analysis using SmartPLS Version 3.2.9 (2021).

\section{Discussion}

Job resources have no effect on employee engagement, this means that no matter how good job resources are, they will not give high employee engagement results and vice versa, this result is supported by the results of research by [40] and [19] which provides research results that job resources have no effect on employee engagement but this research is not supported by research by [42] and [41] which state that job resources have a significant positive effect on employee engagement. Judging from the most dominant indicators on the job resources variable, namely promotion and employee engagement, namely enthusiasm, this can be interpreted that existing job promotions cannot significantly increase employee engagement in the company. In the job resources variable, there is a dimension that is not an appropriate 
measuring tool, namely autonomy, so in other words companies that already have SOPs for employees must be able to operate in accordance with established regulations.

$J o b$ resources have a positive and significant effect on workplace spirituality, this research is in line with that conducted by [7] which states that job resources have a positive and significant impact on workplace spirituality, the results of this study have the most dominant indicators, namely promotion and openness. between employees, if seen in the description of respondents based on education as much as $73 \%$ of employees with $\mathrm{S} 1$ education and dominated by the age of 25-35 years and the dominance of positions at the staff level, this means that there are still many opportunities for promotions which will increase the sense of openness among employees caused by one of the characteristics of millennials, namely being able to connect with each other thanks to an internet connection which will later be unlimited in interaction.

Workplace spirituality has no effect on employee engagement, so it can be said that employee engagement will remain low even though workplace spirituality is already high, this statement is not in line with research conducted by [12] and [18] which stated that the more The high values of spirituality in the workplace will make employees increase their relationship as employees, a sense of openness between employees which is the most dominant indicator of workplace spirituality is not able to provide a sense of enthusiasm for employees which is the most dominant indicator of employee engagement. This is also confirmed by a report released by [8] which states that the main characteristic of millennials is that they do not have good relationships at work.

Job resources have no effect on employee engagement mediated by workplace spirituality, meaning that the relationship is not directly mediated workplace spirituality will only further weaken the relationship job resources toward employee engagement, it indicates that a same kin the opportunity to develop as an indicator of the most dominant of job resources given will not improve employee engagement and when added to the sense of openness among employees as the most dominant indicator of workplace spirituality cannot change the relationship of job resources to employee engagement, this statement is supported by [40] and [19] who stated that job resources had no effect on employee engagement and were not supported by research conducted by [42] and [41] stated that job resources had a positive and significant effect [12], [13] and [18] stated that spirituality in the workplace has a significant effect on employee engagement.

Job resources have a positive and significant influence on professional identity, meaning that the higher the existing job resources through the most dominant indicator, namely promotion, the greater the sense of self-understanding when working as the most dominant indicator of professional identity, [28] stated that job resources can predict personal resources such as optimism in doing work and self-efficacy or individual confidence of each employee, [15] also stated that there is a significant positive influence between job resources on employee engagement, in Respondents' descriptions based on position and latest education are dominated at the staff level and at the undergraduate level which will later show that employees will continue to improve their professional identity according to the work they have through the opportunities provided by the company through one of the individuals. The most dominant office job resources providing promotions.

Professional identity has a positive and significant effect on employee engagement, this can mean that an employee will have a good level of employee engagement if the professional identity that is in him is high and vice versa, when individuals have a high professional identity towards their work, they will devote more energy and enthusiasm to their work [26] and [29]. The most dominant indicator of professional identity is the sense of understanding oneself when working, and the most dominant indicator value of employee engagement is enthusiasm so that it can be interpreted that the more employees who believe they have the ability to carry out their duties, the more enthusiastic an employee will be in carrying out their work.

$J o b$ resources have a positive and significant effect on employee engagement mediated by professional identity, job resources that initially had no direct effect on employee engagement became positive and significant when mediated by professional identity, this proves that professional identity mediates perfectly between job resources and employees. engagement, research by [32] shows that staff members with higher education have a professional identity which is considered a factor that influences employee engagement, [10] and [17] state that there is a positive influence between job resources on employee engagement and research by [26] and [29] which states that professional identity has a significant positive effect on employee engagement. By looking at one of the characteristics of the respondents, namely millennial employees who have confidence in life at work, they must have meant, purpose and have growth in the workplace and career is very important, then through a high sense of self-understanding when working, employees will have the confidence to get opportunities develop by providing promotions which will later generate enthusiasm as an indicator of employee engagement.

\section{CONCLUTION AND SUGGESTION}

\section{A. Conclution}

Based on the results of the research above, it can be concluded that job resources have no effect on employee engagement, meaning that no matter how good the work resources are, it will not increase employee engagement, job resources have a positive and significant effect on workplace spirituality, meaning that the better the existing job resources. it will increase the spirituality in the workplace, workplace spirituality does not significantly influence employee engagement means as well as any workplace spirituality in the company can't increase employee engagement, an indirect relationship mediated by workplace spirituality is not able to give effect between job resources toward employee engagement means more both the job resources that have been provided will not increase employee engagement and when added to the workplace spirituality mediation variable , it cannot change the relationship of limited job resources and employee engagement, job resources have a positive and 
significant effect on employee engagement, meaning that the better job resources in the company, the more professional identity of each employee will be. Professional identity has a positive effect on employee engagement, meaning that the higher the professional identity in the employee will be increase employee engagement given to the company, the indirect relationship mediated by professional identity can mediate or it can be said that it will improve the relationship between job resources and employee engagement.

\section{B. Suggestion}

Optimizing the effectiveness and opportunities for employee development through promotions by taking advantage of the characteristics of millennials who want to change positions and careers more quickly. Companies can conduct job analysis and evaluation on a regular basis, add programs such as job clusters millennials are also connected to each other thanks to an internet connection so that they interact globally, it is not limited, so companies can create sharing circles in the form of whatsapp groups, google groups or weekly, monthly / yearly sharing meetings, provide training or seminar conferences according to the employee's profession and employee level and also companies can create innovative programs namely by looking at the achievements of employees, they will be challenged to make short-term projects, giving awards to employees who have succeeded in producing innovations in the work process where the award can be in the form of financial, training or site visits innovative office.

\section{Limitations and Further Directions}

Data collection in this study applies a saturated sample where the entire population is used as a data sample, so that future researchers can use different sampling. The data collection process is carried out online so that future researchers can add a data collection process that is carried out directly so that it can be monitored to prevent bias, the development of research models by developing more varied populations and samples and in this study the cause of employee engagement is only limited to the job variable. Resources, workplace spirituality and professional identity, so that further researchers can add or use other variables.

\section{REFERENCES}

[1] Abdillah, W. Hartono, J. (2015). Partial least square (PLS): alternatif structural equation modeling (SEM) dalam penelitian bisnis. Yogyakarta: Andi.

[2] Albrecht, S L. Marty, A. (2017). Personality, self-efficacy and job resources and their associations with employee engagement, affective commitment and turnover intentions. The International Journal of Human Resources Manahement. 0958-5192, DOI: 10.1080/09585192.2017.1362660.

[3] Aprilia, S. Palupiningdyah. (2019). The Role Mediation in Improving Workplace Spirituality. Management analysis Journal, 8(4), 22526552.

[4] Ayu, DR. Maarif, S. Sukmawati, A. (2015). Pengaruh Job Resources Dan Personal Resources Terhadap Work Engagement. Jurnal Aplikasi Bisnis dan Manajemen (JABM), 1(1), 2460-7819, DOI: 10.17358/JABM.1.1.12.

[5] Bakker, BA. Demerouti, E. (2016), Job Demands - Resources Theory: Taking Stock and Looking Forward, Journal of Occupational Health Psychology At 20.

[6] Bank Muamalat, Annual Report 2019

[7] Bickerton, R. Grant. Miner,H. Maureen. Dowson, M. Griffin, B. (2014). Spiritual Resources in The Job Demands - Resources Model
Journal of Management, Spiritualty \& Religion. 11(3), 245-268, DOI:10.1080;14766086.2014.886517.

[8] Crabtree, S. (2013). Worldwide, $13 \%$ of employee engagement are engaged at work: low workplace engagement offers opportunities to improve business outcomes. Diunduh pada 9 November 2020 dari http://www.gallup.com.

[9] Dale Carnegie Editor (2016), Hanya 25 persen millennials yang setia kepada perusahaan.

[10] Deviyanti,A.D. Sasono, Agus Dwi. (2015). Pengaruh Sumber Daya Pekerjaan (Job Resources) dengan Keterikatan Kerja (Work Engagement) Sebagai Mediator Terhadap Perilaku Proaktif (Studi Pada Karyawan PT RGA Internasional Indonesia). Jurnal Ilmu Manajemen Magistra, 1(1), 2442-4315.

[11] Ferreira, Pedro. (2020). Employee Engagement in Tourism: A Generational Study of European Countries. Cuadernos de Turismo, 349-365, DOI: https://doi.org/10.6018/turismo.451871.

[12] Herlina, A. Mujib, A. (2017). Impact Of Social Support, Psychological Capital, And Workplace Spirituality to Employee Engagement at Company. Journal of Psychoology. 22(1).

[13] Iqbal, M. Adawiyah, WR. (2019). Exploring The Impact of Workplace Spirituality on Nurse Work Engagement: An Empirical Study on Indonesian Government Hospitals. International Journal of Ethics and Systems, 2514-9369, DOI: 10.1108/IJOES-03-2019-0061.

[14] Kamble, RA. Mulla, Z. (2019). Professional Identity Neutralizes Charismatic Leadership Tactics in A Crisis. Journal of Indian Business Research. 12(3), Pp 411-425. 1755-4195, DOI: 10.1108/JBR-05-2019-0152.

[15] Keyko, K. Cummings. GG. Yonge, O. Wong, CA. (2016). Work Engagement in Professional Nursing Practice: A systematic review. International Journal Of Nursing Studies 61, 142-164, DOI: 10.1016;j.ijnurstu.2016.06.003.

[16] Kwon, K. Kim, T. (2019). An integrative literature review of employee engagement and innovative behavior: Revisiting the JD-R model. Human Resources Management Review DOI:10.106/j.hrmr.2019.100704.

[17] Malinowska, D. Tokarz, A. (2020). The Moderating role of Self Determination Theory's general causality orientations in the relationship between the job resources and work engagement of outsourcing sector employees. Personality and Individual Differences 153, DOI:10.1016.j.paid.2019.109638.

[18] Milliman, J. Gatling, A. Kim, J (sunny). (2018). The Effect of Workplace Spirituality on Hospitality Employee Engagement, Intention to Stay, and Service Delivery. Journal of Hospitality and Tourism Management 35. 56-65, DOI: 10.1016/j.jhtm.2018.03.002.

[19] Nikolova, I. Schaufeli, W. Notelaers, G. (2019). Engaging leader Engaged employees? A cross-lagged study on employee engagement. European Management Journal, DOI:10.1016/j.emj.2019.02.004.

[20] Otoritas Jasa Keuangan (2015), Roadmap Perbankan Syariah Indonesia 2015-2019.

[21] Pamungkas, GB. Sulistyo, H. (2020). Peran Organizational justice dan Spirituality Management Terhadap Employee Engagement dan Turnover Intention dengan moderasi Locus of Control. Jurnal Bisnis: Teori dan Implementasi. 11(2). 20185-7721.

[22] Sharma, PK. Kumra, R. (2020). Relationship Between Workplace Spirituality, Organizational Justice and Mental Health: Mediation Role of Employee Engagement. Journal of Advances in Management Research, 0972-7981, DOI: 10.1108/JAMR-01-2020-0007.

[23] Siswanto, A. Farid, MF. Misno, A. Arijulmanan. Syarif, A. Fahmi, Abu. (2020). HRD Syariah Teori dan Implementasi.Jakarta: Gramedia Pustaka Utama.

[24] Sridevi, M. Sandhya. (2010), Employee Engagement: The Key to Improving Performance. Internasional Journal of Business and Management, 5(12). 1883-380.

[25] Sugiyono. (2014). Metode Penelitian Pendidikan Pendekatan Kuantitatif, Kualitatif dan $R \& D$.Bandung: Alfbeta.

[26] Wang, C. Xu Jiahui. Zhang, TC. Li, QM. (2020). Effects of professional identity on turnover intention in China's hotel employees: The mediating role of employee engagement and job satisfaction. Journal of Hospitality and Tourism Management 45, 1022, DOI: 10.106/j.jhtm.2012.07.002.

[27] Wati, LN. (2017). Metodologi Penelitian Terapan. Mujahid Press. Bandung.

[28] Xanthopoulou, Despoina. Bakker, AB, Demerouti, Evangelia Schaufeli, Wilmar B (2009). Reciprocal relationship between job resources, personal resources, and work engagement. Journal of Vocational Behavior 74, 235-244, DOI: 10.1016/j.jvb.2008.11.003.

[29] Zhang, W. Meng, H. Yang, S. Liu, D. (2018). The Influence of Professional Identitiy, Job Satisfaction, and Work Engagement on Turnover Intention among Township Health Inspectors in China. 
International Journal of Enviromental Research and Public Health, 15(988), DOI: 10.3390/ijerph15050988.

[30] I. Ghozali and H. Latan, Konsep, Teknik, Aplikasi Menggunakan Smart PLS 3.0 Untuk Penelitian Empiris. Semarang BP Undip, 2015.

[31] A. Ferdinand, Metode Penelitian Manajemen, Edisi 5. Semarang: Seri Pustaka Kunci, 2014.

[32] Zhou, X., Ma, J., \& Dong, X. (2018). Empowering supervision and service sabotage: A moderated mediation model based on conservation of resources theory. Tourism Management, 64, 170-178.

[33] Schaufeli, W. B., \& Bakker, A. B. (2004). Job demands, Job resources, and their relationship with burnout and engagement: A multi-sample study. Journal of Organizational Behavior, 25(3), 293-315.

[34] Ashmos.D. (2000). Spirituality At Work Conceptualization and Measure. Journal Of Management Inquiriy. 9(2), 137 - 138.

[35] Armstrong, Michael. (2009). Armstrong's Handbook of Performance Managementm, $4^{\text {th }}$ edition. Kogan Page. London.

[36] Stiadi. Doni, C. Mieske. R. Ahmad, F. Ikhwan, and S. Ahmad. (2017). Model Hubungan workplace spirituality Terhadap Organizationan Commitment Dan Organizational Citizenship Behavior Pada lembaga Pendidikan. Prosiding Seminar Nasional AIMI, 27-28.

[37] Ibanescu,A. (2015). How Do Novice Specialist In Human Resources Develop Their Proffesional Identity? Procedia - Social and Behavioral Scinces 187, 596-600.

[38] Mancini, \& Caricati (2015). Personal and Social Aspects Of Professional Identity An Extension Of Marcia's Identity Status Model Applied To A Sample Of University Students. Journal Of Vocational Behavior, 89, 140-150.

[39] Anvari.R, Barzaki.A.S, Amiri.L, Irum. S and Shapourabadi.S. (2017). The Mediating Effect Of Organizational Citizenship Behavior On The Relationship Between Workplace Spirituality And Intention To Leave. Intangible Capital,DOI: https://doi.org/103926/ic.906.

[40] Balwant. P.T, Mohammed. R and Singh. R. (2019). Transformational Leadership and Employee Engagement In Trinidad's Service SectorThe Role Of Job Resources, International Journal of Emering Markets. 15(4), DOI: 10.1108/IJOEM-01-2019-0026.

[41] Radic. A, Arjona-Fuentes. J.M, Ariza-Montes.A, Han. Heesup, Law.R. (2020). Job Demands - Job Resources (JD-R) Model, Work Engagement, And Well-Being Of Cruise Ship Employees. International Journal of Hospitality Management. DOI 10.1016/j.ijhm.2020.102518.

[42] Kotze. Martina. (2018). How Job Resources And Personal Resources Influence Work Engagement And Burnout. African Journal Of Economic And Management Studies. DOI: 10.1108/AJEMS-05-20170096.

[43] Shohib.M and Hadi. C. (2020). Spiritualitas di Tempat Kerja dan Keterikatan Karyawan.ejournal.umm.ac.id/index.php/cognicia. 